\title{
Effect of Entrepreneurship Education on Students Orientation Towards Entrepreneurship at the Malawi Polytechnic
}

\author{
Charles Mwatsika, Eric Sankhulani \\ Management Studies Department, University of Malawi, Blantyre, Malawi \\ Email address: \\ cmwatsika@poly.ac.mw (C. Mwatsika), esankhulani@poly.ac.mw (E. Sankhulani)
}

\section{To cite this article:}

Charles Mwatsika, Eric Sankhulani. Effect of Entrepreneurship Education on Students Orientation Towards Entrepreneurship at the Malawi Polytechnic. International Journal of Business and Economics Research. Vol. 5, No. 6, 2016, pp. 235-245. doi: 10.11648/j.ijber.20160506.17

Received: September 28, 2016; Accepted: October 7, 2016; Published: December 14, 2016

\begin{abstract}
Entrepreneurship education has proliferated in universities following empirical studies linking it to entrepreneurship practice. The University of Malawi introduced entrepreneurship and innovation course to the bachelor of business administration programme and aims to make entrepreneurship a core module across academic programmes. This study assessed the effects of the entrepreneurship and innovation course on the entrepreneurial orientation of students thereby joining research into the investigation of the effects of entrepreneurship education on entrepreneurial orientation of students. A questionnaire was administered on a class of 58 students before commencement of the course and at the end of the course delivery to assess movement in students knowledge about entrepreneurship, attitudes towards entrepreneurship, subjective norms, self efficacy and entrepreneurial intentions that could be attributed to entrepreneurship education holding other factors constant over the period of study. The study found that entrepreneurship education positively effects students knowledge about entrepreneurship and their self efficacy; the self confidence in skills and competences that they can engage in entrepreneurship successfully. The study however found weak correlation between entrepreneurship education and students attitudes towards entrepreneurship and their entrepreneurial intentions and did not find any relationship between entrepreneurship education and students' subjective norms. Although attitudes, subjective norms and self efficacy are factors that influence intentions, which are an antecedent of behaviour within the Theory of Planned Behaviour, the study found that entrepreneurship education positively and significantly effects self efficacy only within this framework.
\end{abstract}

Keywords: Entrepreneurship Education, Attitudes, Subjective Norms, Self Efficacy and Intentions

\section{Introduction}

Entrepreneurship is a buzz word across nations in the $21^{\text {st }}$ century despite, according to Herbert and Link (1988), the concept being as old as the institutions of barter and exchange. Today economic performance of countries of the world is unstable. Globalisation and reduction in trade barriers, advancement in information technology and telecommunication and other macro dynamics have provided new opportunities as well as increased business uncertainty and complexity. Organisations have responded to the uncertainty and complexity by restructuring, downsizing operations, re-engineering business operations, increasing strategic alliances, merging and other organisations have failed to respond and have collapsed.
There is continued increasing economic uncertainty, poor economic performance, poverty and unemployment in countries such as Malawi. In the prevailing circumstances, entrepreneurship has been widely tipped as a key element, pivotal to economic revitalisation. This is due to the fact that research has shown that entrepreneurship is responsible for the creation of innovations that improve competitiveness of firms, creation of wealth, jobs and economic growth (Acs and Audretsch, 2003; Aidis, 2005; Benzing et al, 2009). Because literature has cited lack of entrepreneurship as the main cause of a country's low levels of economic activities, entrepreneurship is receiving more attention from governments and organisations in economic planning and development.

In Malawi, development of entrepreneurship is strategic to 
economic growth. Several programmes, initiatives and organisations were established to develop entrepreneurship, small and medium enterprises and rural growth centres where entrepreneurship is of central focus. Institutions of Higher Education (IHE) as strategic partners to the economic development process, responded to entrepreneurship development by introducing courses and programmes in entrepreneurship education. The University of Malawi (UNIMA) adopted entrepreneurship as its core value and introduced entrepreneurship courses and programmes and aims to offer entrepreneurship education across academic programmes. UNIMA wants to graduate entrepreneurship minded persons who will create jobs and play a role in the development of Malawi through venture creation and/or entrepreneurial management of existing entities.

The drive towards advancement of entrepreneurship education has been fuelled by various researches that successfully established the link between (entrepreneurship) education attainment and entrepreneurial activities (Brooksbank and Jones-Evans, 2005; Delmar and Davidsson, 2000; Dickson et al, 2008; Dumas, 2001; Kolvereid and Moen, 1997; Mc Larty, 2005; Osborne et al, 2000; Peterman and Kennedy, 2003; Robinson and Sexton, 1994; Schwarz et al, 2009; Souitaris et al, 2007). The research findings linking entrepreneurship education to entrepreneurial activity therefore necessitated the increase in the number of entrepreneurship courses offered by IHE (Katz, 2003) and in Malawi, universities have likewise responded by developing and offering courses and programmes in entrepreneurship.

The Problem and Research Objective

IHE introduced entrepreneurship education in response to various research findings that linked positively entrepreneurship education and entrepreneurial activity among graduates. Although the expected impact of entrepreneurship education may be common, that is contributing to economic growth through increased entrepreneurial activities and enterprise development among graduates, the outcomes of entrepreneurship education from IHE may not be the same and therefore not able to produce similar desired impacts. UNIMA wants to develop entrepreneurial mindsets of its graduates under the prevailing economic situation of rising unemployment and not so positive view of small enterprise ownership as a career option.

Studies have been conducted elsewhere whose findings show the correlation between entrepreneurship education and entrepreneurial orientation of students. However, not all entrepreneurship modules and programmes in IHE are structured the same way nor deploy similar pedagogical approaches for teaching of entrepreneurship. It is therefore prudent to not expect similar outcomes from entrepreneurship education from different IHE in changing entrepreneurial orientation of students.

The Polytechnic of UNIMA introduced Entrepreneurship and Innovation course to the Bachelor of Business Administration programme at year three. However, no studies had been conducted to find out the effectiveness of this entrepreneurship education in influencing entrepreneurial orientation of students that can feed into the recommendations for adoption of entrepreneurship courses across other academic programmes or the development of entrepreneurship degree programmes. Collins, Hannon and Smith (2006) observed that little is known about the actual impacts of entrepreneurship education programmes on developing entrepreneurial intentions of students particularly in universities. Souitaris et al (2007) pointed to the lack of understanding of factors that affect students' intentions of becoming entrepreneurs and the relationship between entrepreneurship education and students' entrepreneurial attitudes and intentions.

This study was therefore conducted to assess the effect of the Entrepreneurship and Innovation course offered to the third year students of the Bachelor of Business Administration programme at the Polytechnic of UNIMA thereby investigating the effects of entrepreneurship education on students' orientation towards entrepreneurship. The study tried to respond to the question, whether entrepreneurship education affects students attitudes, subjective norms, self efficacy and entrepreneurial intentions as provided in the Theory of Planned Behaviour (TPB). Specifically the study (1) assessed the movement of students knowledge about entrepreneurship, (2) assessed movement of students' attitudes towards entrepreneurship, (3) assessed movement in students' subjective norms, (4) assessed movement in students' perceived self efficacy, and (5) assessed movements in students' entrepreneurial intentions. The aim was to understand with implications the effects of entrepreneurship education on students' orientation towards having entrepreneurship as an alternative career option post graduation.

\section{Materials and Methods}

\subsection{Research Model}

The research adopted the Theory of Planned Behaviour (TPB) (Ajzen, 1991) to investigate the effect of entrepreneurship education on attitudes, subjective norms, Perceived Behavioural Control (PBC)or self efficacy and intentions of students towards entrepreneurship. Statements for measuring each element were adopted from empirical studies and modified to suit the context of the study. The study was conducted on the Bachelor of Business Administration students of UNIMA by use of a questionnaire. The questionnaire was administered to the class at the beginning of a semester, before commencement of entrepreneurship course delivery and the same questionnaire was administered to the same class at the end of semester, at the end of course delivery. Administration of the questionnaire at the start and end of semester enabled assessment of the movement in students' knowledge about entrepreneurship, attitudes towards entrepreneurship, subjective norms, self efficacy and entrepreneurial intentions as highlighted in the TPB (Ajzen, 1991) to determine 
movement that could be attributed to the entrepreneurship education holding other factors constant over the period of study.

\subsection{Research Questionnaire}

The questionnaire was structured to collect demographic details of the students such as gender and age in the first section. Gird and Bagraim (2008) found that prior experience of entrepreneurship significantly added to the predictive power of the TPB in explaining entrepreneurial intentions and Krueger (1993) found that prior exposure to entrepreneurial activities such as family business influences attitudes towards entrepreneurship. It is further argued in literature that prior exposure through direct experience in starting or attempting to start a new business would affect attitudes and perceptions about entrepreneurship as a career.

Therefore the study collected students' background data on whether (1) the student had previously undertaken training in entrepreneurship (2) if the student's father, mother or guardian owned, ran own business venture and (3) whether the student had ever started or tried to start and run a small business before. This data was collected to assess any implications and differences in students' entrepreneurial orientation at the onset of entrepreneurship education. The measurement of students knowledge about entrepreneurship was done by asking the students to tick the statements that related to entrepreneurship. The statements included: Entrepreneurship involves; starting a new business venture, creating an innovative product or service, inventing a new production process, finding a new market for a product or service, finding a new way of doing something, none of the above and I don't know.

The TPB contends that intentions are an antecedent of behaviour and in turn intentions are influenced by attitudes, subjective norms and PBC (Ajzen, 1991) therefore attitudes, subjective norms, PBC (self efficacy) and entrepreneurial intentions were measured on 5 point Likert scale where the respondents were requested to rate their agreement or disagreement with the statements as they applied to them on the scale where 1 was 'Strongly disagree' and 5 was 'Strongly agree' with the statement.

The statements of attitude were adopted and modified from Kolvereid (1996) and other empirical studies. They included both self employment and employment attitude measures such as; strong desire to be own boss, enjoyment of challenging work, desire to create something new, desire to be involved in running of the whole business, desire to have job security and stability, desire to climb up the organisational ladder and desire to have fixed working hours. Students' feelings about running own business ventures, how tense they would be to run a business and how enthusiastic they would be about running a business were measured to assess their attitudinal disposition towards entrepreneurship. The subjective norms were measured by assessing the influence of family, friends and colleagues, and other people considered important by respondents in perceiving entrepreneurship. Subjective norms were measured as the key influencing factors to the participants considering to become entrepreneurs someday.

PBC/self efficacy among students was measured by requesting the participants to rate their self belief (confidence) that they had adequate skills and competences in areas of entrepreneurship, marketing, finance and management necessary to successfully start and run their own business ventures. These are the areas the Business Administration programme endeavours to develop among students and it was necessary to assess how confident the students felt they had the requisite skills at the start of their third year classes to compare with the level of confidence at the end of the third year of learning. Statements for measuring students' entrepreneurial intentions were also adopted from Kolvereid (1996) and Krueger (2000) and then modified to suit the questioning for the study. There were five statements that included: I will choose a career as an entrepreneur, I will make every effort to start and run my own business, I have strong intention to start a business some day, I have thought seriously to start my own business after completing my study, I will start my business in the next 5 years after graduation and I will start my business in the next 10 years after graduation. To condense students' entrepreneurial intentions, participants were requested to estimate their likelihood of starting a business or becoming self employed one year after graduation and 5 years after graduation.

The Cronbach's alpha for the measurement scale was 0.733 demonstrating that the scale had internal consistency to provide valid statistical measures (Nunnally, 1994).

\subsection{Limitation}

The study involved a smaller sample, limited to the students of the public university in Malawi that could have a different culture, experience, exposure, and pedagogical approaches to learning, to quality for immediate transfer of research results. The business administration programme is business and entrepreneurship oriented that could have further biased the students orientation towards entrepreneurship.

\section{Literature Review}

\subsection{Concept of Entrepreneurship}

Although entrepreneurship is a concept that lacks a commonly agreed definition (Hornaday, 1992), it is widely understood as starting and running one's own business venture. There are various definitions of entrepreneurship in literature. Dollinger (2003) says entrepreneurship is the creation of an innovative economic organisation (or network of organisations) for the purpose of gain or growth under conditions of risk and uncertainty. Other researchers have defined entrepreneurship as pursuit of opportunity beyond the resources one currently controls whereas the European Commission states that entrepreneurship refers to an individual's ability to turn ideas into action (EC, 2008). 
Shane and Venkataraman (2000) define entrepreneurship as a process by which opportunities to create future goods and services are discovered, evaluated and exploited. The process that is concerned with change, emergence and creation. This study therefore sums up entrepreneurship as a process through which individuals use their abilities to discover, evaluate and exploit business opportunities under conditions of risk and uncertainty, resulting in the creation of innovative economic organisation. Entrepreneurship manifests in the creation of economic value; new products, services and ventures for personal and/or business gain.

At the centre of entrepreneurship is the entrepreneur who, according to Schumpeter (1934), is a person willing and able to convert a new idea or innovation into a successful innovation, simultaneously creating new products and business models, largely responsible for the dynamism of industries and long run economic growth. The manifestations of entrepreneurship are the reason entrepreneurship is taking centre stage in poor economies. It is seen as a driving force of economic development, structural growth and job creation (Autio, 2007) the solution to economic growth, competitiveness of firms and industries, and a strategy for reducing unemployment and poverty.

\subsection{Entrepreneurship Education}

The key components of the entrepreneurship development process are the creation of the entrepreneur and creation of an enabling environment where the entrepreneur is able to actualise the benefits of entrepreneurship. Entrepreneurship education therefore is a key feature of entrepreneurship development process that aims to create the entrepreneur. Shane and Venkataraman (2000) state that entrepreneurship education is about providing potential and future entrepreneurs with knowledge regarding the processes of discovering, creating, evaluating and exploring opportunities to create future goods and services. Entrepreneurship education involves a dynamic process of awareness, reflection, association and application that involves transforming experiences and knowledge into functional learning outcomes (Rae, 2006). It is not under debate anymore whether entrepreneurs can be trained as Drucker (1985) literates that entrepreneurship is not magic, it is not mysterious and it has nothing to do with genes. It is a discipline and like a discipline it can be learned. It is indeed possible to provide individuals with the requisite skills and knowledge required to start and develop a new venture (Gorman et al, 1997; Kuratko, 2005). Most of entrepreneurship education in Malawi is concentrated at university level. Graduates are considered as key to national development. It is believed that inspired self confident, talented entrepreneurial graduates are more likely to found and lead dynamic new business ventures and have capacity to transform existing organisations. The Entrepreneurship and Innovation course, the subject of this study, has a syllabus that focuses on developing useful knowledge for entrepreneurship, stimulating creative thinking, developing attitudes positively disposed to embrace change and entrepreneurial thinking, developing entrepreneurial skills, providing tools for analysing and scanning the business environment, developing a business plan and enthusing students to pursue and support entrepreneurship. Therefore the course provides students opportunities to acquaint themselves with entrepreneurship practice however as noted by Heinonen (2007) providing opportunities for students to experience real entrepreneurial risk taking, creativity and innovation is not easy, more so with the prevailing pedagogical approaches in UNIMA.

In the business administration programme, the entrepreneurship course is complimented by marketing and finance management courses that develop students' marketing and financial skills for running of a business. The primary goal of entrepreneurship education in UNIMA is to increase students awareness of entrepreneurship as a process and attainability of entrepreneurship as a viable career option post graduation similar to the same focus in the USA and Europe as noted by Zeithmal and Rice (1987) and Johannisson et al (1998) respectively. Several studies have associated successful completion of entrepreneurship education with students undertaking business start up activities thereafter (Dickson et al, 2008; Dumas, 2001; Kolvereid and Moen, 1997; Mc Larty, 2005; Osborne et al, 2000). Furthermore Robinson and Sexton (1994), Delmar and Davidsson (2000) and Brooksbank and Jones-Evans (2005) found that educational attainment was positively correlated to entrepreneurial activity thereby giving impetus to this study to assess the effects of entrepreneurship education offered in UNIMA on students' entrepreneurial orientation.

\subsection{Entrepreneurial Intention Models and Research Hypotheses}

Many studies on entrepreneurship orientation and behaviour have been guided by Entrepreneurial Intention Models (EIM) where the Theory of Planned Behaviour (TPB) by Ajzen (1985) is the popular model. TPB stemmed from the Theory of Reasoned Action (TRA) by Fishbein and Ajzen (1980) where the dominant conceptualisation was that social norms and attitude or effect (the positive or negative emotion an individual has about a subject matter) determined behaviour. However, the general consensus from later empirical studies was that measures of attitude alone had little value for the prediction of overt behaviour (Ajzen, 1985). Therefore Ajzen (1985) introduced behavioural beliefs, normative beliefs (normative expectations) and control beliefs as key factors that affect behavioural intentions in the TPB. Behavioural beliefs involve the perceived value an individual would receive from the performance of the behaviour which shapes the attitudes towards the behaviour. The normative beliefs are the social beliefs that influence the individual to behave in a particular way and the control beliefs are the factors that may facilitate or impede performance of a behaviour. Ajzen (1985) referred to the control beliefs as Perceived Behavioural Control (PBC), the individual's perceived controllability of the 
outcome of behavioural performance.

Furtherance to the understanding of EIM, Bandura (1986) introduced the concept of perceived self efficacy as a determinant of behavioural intentions. Bandura (1977) defines self efficacy as the individuals self confidence to engage successfully with a behaviour. This understanding brought a different conceptualisation of PBC. Studies by Armitage and Conner (1999, 2001b) demonstrated that self efficacy and $\mathrm{PBC}$ are separate constructs then Elfving, Brannback and Carsrud (2009) provided a theoretical view that self efficacy is a predictor of feasibility not controllability, and that social norms are mediated by perceived desirability of entrepreneurship. This view therefore put question marks on the influence of $\mathrm{PBC}$ on behavioural intentions because perceived feasibility and not perceived controllability of behavioural outcomes was deemed a significant predictor of intentions. Ajzen (2002) then suggested that in $\mathrm{PBC}$, it is the perceived difficulty not perceived controllability which added significantly to the prediction of intentions and behaviour. Therefore Ajzen (2002) aligned PBC with Bandura's (1997) self efficacy as being about a behaviours relative difficulty to perform (perceived feasibility) that determine intentions.

Therefore the TPB perceives intentions as a single best predictor of an individual's behaviour, as Fishbein and Ajzen (1975) state that the single best predictor of an individual behaviour is a measure of his intentions to perform that behaviour. According to the theory, the intentions are an antecedent to behaviour and three levels of factors affect intentions and these are attitudes, subjective norms and perceived behaviour control which can be equated to self efficacy as in Figure 1.

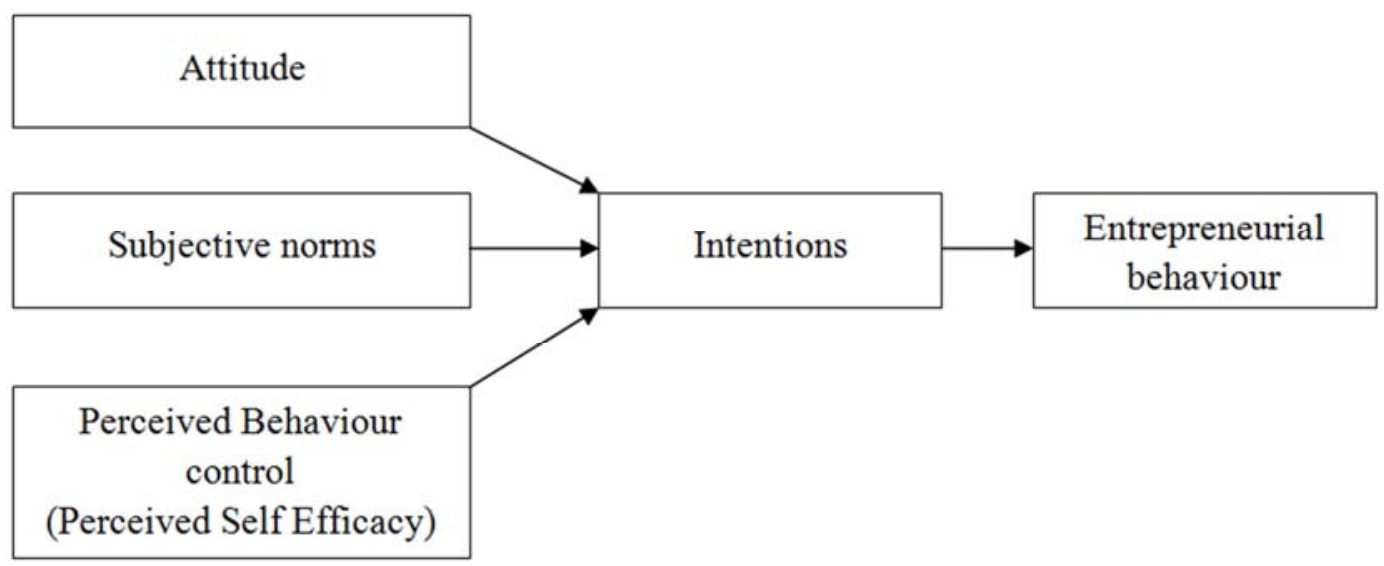

Figure 1. Depiction of Theory of Planned Behaviour (Ajzen,1991).

Bird (1988) define entrepreneurial intentions as the state of mind directing a person's attentions and actions towards self employment and Linan and Rodriguez (2004) refer to intentions as the efforts of a person to carry out entrepreneurial behaviour. Various research have found a strong link between intentions and actual behaviour both within entrepreneurship and in a wide variety of situations (Douglas and Sheppard, 2002; Sheppard and Warshaw, 1988). Intentions are seen as the cause of an action and Chandrashakaran et al (2000) found that the higher the stated intentions to execute the action, the higher the probability of engaging in the act. Linan and Rodriguez (2004) supports the TPB that intentions are a function of personal attitude, perceived self efficacy and perceived subjective and social norms.

Personal attitude is defined as a mental and neural state of exerting readiness, exerting a directive or dynamic influence upon the individual regarding objectives and situations (Allport, 1935). Ajzen (1991) asserts that attitude is influenced by individual's expected value from executing the behaviour which Shapero (1982) calls specific desirabilities. Literature posits that entrepreneurship is affected by external factors and these include the status of the economy, availability of venture capital, government policy and regulation, but holding these factors constant, human motivation plays a critical role in the entrepreneurship process and that motivation is influenced by the attitude towards entrepreneurial behaviour under consideration.

The other antecedent of entrepreneurial intentions is self efficacy which Bandura (1997) defined as a strong personal belief in skills and abilities to initiate a task and lead it to success. Markman et al (2002) contends that it is the perceptions of self efficacy rather than objective ability that motivate individuals to demonstrate entrepreneurial behaviour; a person having strong belief in his/her capabilities to perform actions and activities that are needed for achieving the desired outcomes and goals (Boyd and Vozikis, 1994). Self efficacy (Bandura, 1997) is equated to PBC (Ajzen, 2002) meaning the perceived difficulty (feasibility) of successfully engaging with an entrepreneurial behaviour.

The third element of subjective norms refer to influence on entrepreneurial intentions based on the beliefs, culture, messages about what is good and positive, what lends status and what is valued by others. Not many studies have linked subjective norms to entrepreneurship education but family background and parental role modelling have been found to be the most prominent factors that affect early socialisation and hence formation of subjective norms and attitudes towards entrepreneurship (Mathews and Moser, 1995; Scott and Twomey, 1988). 
Entrepreneurship is a behaviour (Douglas and Sheppard, 2002) and is regarded as a type of business acumen which may be enhanced through improvements in know-how, skills and competencies (Drucker, 1985; Gorman et al, 1997; Kuratko, 2005). Entrepreneurship education, it is argued, can increase students interest in entrepreneurship as a career. From the time Collins, Hannon and Smith (2006) questioned the actual impacts of entrepreneurship education programmes on developing entrepreneurship intentions of students particularly in universities, several studies have linked the factors that influence entrepreneurial behaviour to education. Peterman and Kennedy (2003), Souitaris et al (2007), and Wilson et al (2007) found that exposure to entrepreneurship education increases entrepreneurial intentions, whereas Bandura (1997), and Hollenbeck and Hall (2004) found that entrepreneurship education can enhance an individual's level of self efficacy. According to Wilson et al (2007) education enhances self efficacy by providing knowledge and skills to cope with competences embedded in entrepreneurial tasks such as opportunity seeking, resource assembling and leading the business to success. Donkels and Miettinen (1997) says the main role of entrepreneurship education becomes to raise consciences and acceptance of new venture creation as a realistic and profitable career option.

Whilst this research was conducted to assess the effect of the Entrepreneurship and Innovation course in UNIMA, it joined empirical studies in investigating the effect of entrepreneurship education on the orientation of students towards entrepreneurship as a career option post graduation and assessed the links between entrepreneurship education and the factors within the TPB. Therefore based on the literature herein reviewed and the TPB, the following hypotheses were generated:

H1 Entrepreneurship education positively effects students attitudes towards entrepreneurship,

H2 Entrepreneurship education positively effects students self efficacy

H3 Entrepreneurship education positively effects students subjective norms

H4 Entrepreneurship education positively effects students entrepreneurial intentions

\section{Results and Discussion}

The study was conducted on a class of 58 Bachelor of Business Administration third year students. Their entrepreneurship knowledge, attitudes, subjective norms, self efficacy and entrepreneurial intentions were measured before the start of entrepreneurship course delivery coded Batch 1 (B1) and measured again at the end of learning coded Batch 2 (B2).

The class comprised 36 percent female students and 64 percent male students with the majority ( 84 percent) in the age group of 15 to 25 years and 14 percent between 26 and 35 years. None of the students had entrepreneurship education before the commencement of the entrepreneurship course, 41 percent of the students had a father, mother or guardian who owned and ran a business venture and 58 percent of the students had started or tried to start and run a small business venture before the course delivery. However, cross tabulation and chi-square tests showed that there were no statistical differences in responses among the students due to these background differences.

\subsection{Students Knowledge About Entrepreneurship}

According to Schumpeter (1934) entrepreneurial change manifests in new (improved) products, services, new markets, new methods of production, new sources of supply and new business management processes and starting a new business venture is an entrepreneurial activity. Therefore students' knowledge about entrepreneurship was tested by asking them to tick statements that related to entrepreneurship among five statements.

Table 1. Students responses on the meaning of entrepreneurship before and after education.

\begin{tabular}{llll}
\hline No & Item & $\begin{array}{l}\text { B1 } \\
\text { Percent }\end{array}$ & $\begin{array}{l}\text { B2 } \\
\text { Percent }\end{array}$ \\
\hline & Entrepreneurship relates to: & & \\
1 & Starting a new business venture & 74 & 91 \\
2 & Creating an innovative product/service & 72 & 90 \\
3 & Inventing a new production process & 57 & 79 \\
4 & Finding a new market for products/services & 47 & 86 \\
5 & Finding a new way of doing things & 36 & 79 \\
6 & None of the above & 2 & 0 \\
7 & I Don't know & 5 & 0 \\
\hline
\end{tabular}

The results in Table 1 show that there was significant positive movement in students' knowledge about entrepreneurship after the course delivery. At the beginning of the course delivery, 2 per cent of the students did not think any of the statements related to entrepreneurship and 5 per cent simply did not know. However, at the end of the course delivery none of the students didn't know or even failed to relate any of the statements to entrepreneurship. There was a sharp increase in the number of students who related each statement to entrepreneurship at the end of course delivery. Finding a new market for products/services and finding a new way of doing things were considered acts of entrepreneurship by less than 50 percent of the class before education but after entrepreneurship education, over 80 percent of the class considered finding a new market for products/services and finding a new way of doing things, acts of entrepreneurship. Therefore the study results demonstrate that overall entrepreneurship education positively effects students knowledge about entrepreneurship.

\subsection{Students Attitudes Towards Entrepreneurship}

Students attitudes towards entrepreneurship were measured before and after entrepreneurship education by rating students' agreement with employment and self employment statements adopted from empirical studies on a 5 point Likert scale where 1 was 'Strongly disagree' and 5 was 'Strongly agree' to assess movement attributable to entrepreneurship education holding all other factors constant during the period of study. The results are presented in Table 2 . 
The results show that there was statistically insignificant movement in students attitudes statement ratings that could be attributed to entrepreneurship education. Although the attitudes ratings were already high at the start of entrepreneurship course delivery, the notable attitude movement were the downward movement in ratings of employment related statements. The 'desire to have job security and stability'; and the 'desire to work and climb up the organisational ladder' dropped from 88 percent to 69 percent and 77 percent to 39 percent respectively. However, when 'How tense and how enthusiastic' students would feel about running their own business was measured, it remained the same before and after entrepreneurship education.

Table 2. Students agreement with attitude statements.

\begin{tabular}{|c|c|c|c|c|}
\hline No & Attitude Statement & $\begin{array}{l}\text { B1 } \\
\text { Percent }\end{array}$ & $\begin{array}{l}\text { B2 } \\
\text { Percent }\end{array}$ & $\begin{array}{l}\text { Sig. } \\
\mathbf{P}<.005\end{array}$ \\
\hline 1 & $\begin{array}{l}\text { I have strong desire to be my } \\
\text { own boss }\end{array}$ & 93 & 97 & .204 \\
\hline 2 & I enjoy doing challenging work & 78 & 86 & .942 \\
\hline 3 & $\begin{array}{l}\text { I have desire to create something } \\
\text { new }\end{array}$ & 95 & 91 & .383 \\
\hline 4 & $\begin{array}{l}\text { I have desire to be involved in } \\
\text { running of whole business }\end{array}$ & 84 & 88 & .032 \\
\hline 5 & $\begin{array}{l}\text { I have desire to have job security } \\
\text { and stability }\end{array}$ & 88 & 69 & .076 \\
\hline 6 & $\begin{array}{l}\text { I have desire to work and climb } \\
\text { up the organisation ladder }\end{array}$ & 77 & 39 & .078 \\
\hline 7 & $\begin{array}{l}\text { I have desire to have fixed work } \\
\text { hours }\end{array}$ & 27 & 26 & .863 \\
\hline
\end{tabular}

Therefore the study found that entrepreneurship education insignificantly but positively effects attitudes towards entrepreneurship by reducing attitudes towards employment. The fact that the focus of the Business Administration programme is to develop graduates that are able to lead and manage small to large business entities, the students who join the programme are already positively disposed towards business management and entrepreneurship. However, the chi-square tests show statistically insignificant relationship between entrepreneurship education and students attitudes towards entrepreneurship. Therefore the results do not deny but weakly support the Hypothesis - H1 that entrepreneurship education effects attitudes towards entrepreneurship.

\subsection{Students Subjective Norms and Entrepreneurship Education}

Subjective norms refer to influence on entrepreneurial intentions based on beliefs, culture and messages about what is good and positive, what lends status and what is valued by others. Subjective norms were scaled as perception statements of the factors that would influence a student to consider entrepreneurship as an alternative career option and were measured before and after entrepreneurship education.

The results in Table 3 show that less than 50 percent of the students agreed/strongly agreed with subjective norm statements being the reasons for desire to engage in entrepreneurial activities. There was further negligible movement between students agreement on each statement after entrepreneurship education. Further the chi-square tests showed no statistical relationship between subjective norms and entrepreneurship education.

Table 3. Students agreement with statements of subjective norms as reasons for entrepreneurship intentions.

\begin{tabular}{|c|c|c|c|c|}
\hline No & Subjective Norm Statements & $\begin{array}{l}\text { B1 } \\
\text { Percent }\end{array}$ & $\begin{array}{l}\text { B2 } \\
\text { Percent }\end{array}$ & $\begin{array}{l}\text { Sig. } \\
P<.005\end{array}$ \\
\hline & $\begin{array}{l}\text { I would wish to be an entrepreneur } \\
\text { someday because: }\end{array}$ & & & \\
\hline 1 & $\begin{array}{l}\text { There are a number of successful } \\
\text { entrepreneurs among family } \\
\text { members that I am in close contact }\end{array}$ & 28 & 36 & .853 \\
\hline 2 & $\begin{array}{l}\text { There are a number of successful } \\
\text { entrepreneurs among family } \\
\text { members that I know of }\end{array}$ & 42 & 47 & .196 \\
\hline 3 & $\begin{array}{l}\text { I believe that family members who } \\
\text { are close to me think that I should } \\
\text { be an entrepreneur }\end{array}$ & 21 & 26 & .297 \\
\hline 4 & $\begin{array}{l}\text { I believe that people who are } \\
\text { important to me think that I should } \\
\text { be an entrepreneur }\end{array}$ & 32 & 26 & .273 \\
\hline 5 & $\begin{array}{l}\text { If I will be an entrepreneur I will } \\
\text { be appreciated }\end{array}$ & 59 & 57 & .667 \\
\hline
\end{tabular}

Therefore the study results do not support the Hypothesis $\mathrm{H} 3$ that entrepreneurship education effects students subjective norms. There are however, existing myths entrenched in local contexts, cultures and beliefs about entrepreneurship practice and requirements for success that are mired in black magic and sorcery that negatively affect perceptions about successful entrepreneurs and entrepreneurship. It might be in that context that entrepreneurship education could dispel the myths and enhance entrepreneurial orientation by correcting those subjective norms/beliefs about entrepreneurship usually encountered in rural entrepreneurship development.

\subsection{Students Self Efficacy and Entrepreneurship Education}

Students rated their belief in their capabilities to engage successfully in entrepreneurial activities in a number of skills before and after delivery of the entrepreneurship course and other business management courses. The results are presented in Table 4

Table 4. Students agreement with statements of self confidence in skills for entrepreneurship.

\begin{tabular}{lllll}
\hline No & Self efficacy statements & $\begin{array}{l}\text { B1 } \\
\text { Percent }\end{array}$ & $\begin{array}{l}\text { B2 } \\
\text { Percent }\end{array}$ & $\begin{array}{l}\text { Sig. } \\
\mathbf{P}<.005\end{array}$ \\
\hline 1 & $\begin{array}{l}\text { I have strong marketing ability to } \\
\text { run my own business }\end{array}$ & 45 & 86 & .000 \\
\hline $\begin{array}{l}\text { I have adequate managerial skills } \\
\text { to run my own business }\end{array}$ & 39 & 88 & .000 \\
3 & $\begin{array}{l}\text { I have adequate financial skills to } \\
\text { run my own business }\end{array}$ & 36 & 71 & .005 \\
\hline $\begin{array}{l}\text { I have adequate marketing skills to } \\
\text { sell and promote my products and }\end{array}$ & 31 & 84 & .000 \\
\hline 5 & $\begin{array}{l}\text { I have entrepreneurial skills to run } \\
\text { my own business }\end{array}$ & 31 & 91 & .000 \\
\hline $\begin{array}{l}\text { I need to learn entrepreneurship } \\
\text { skills to start my own business }\end{array}$ & 93 & 60 & .002 \\
\hline
\end{tabular}


The results show that the number of students that agreed/strongly agreed that they had skills in the areas of marketing, management, finance and entrepreneurship significantly increased after the course deliveries. At third year of the programme, students take entrepreneurship, marketing, finance and other management courses and the chi square tests show that there was a statistically significant link between education and students' self efficacy to successfully start and run their own businesses. The results support Bandura (1986) and Hollenbeck and Hall (2004) who found that entrepreneurship education can enhance an individual's level of self efficacy. Wilson, Kickul and Marlino (2007) found that education enhances self efficacy by providing knowledge and skills to cope with competences embedded in entrepreneurial tasks such as opportunity seeking, resource assembling and leading the business to success. The findings of these empirical studies are reflected in the study results in that students felt confident in each of the key areas of marketing, finance, business management and entrepreneurship after studying relevant courses. Therefore the study results supports the Hypothesis - $\mathrm{H}_{2}$ that (entrepreneurship) education positively effects students self efficacy.

\subsection{Students Entrepreneurial Intentions and Entrepreneurship Education}

The entrepreneurial intentions of students were assessed before commencement of the entrepreneurship course and after course delivery. Students rated their agreement or disagreement with entrepreneurship intention statements on a scale of 1 to 5 where 1 was 'Strongly disagree' and 5 was 'Strongly agree'.

Table 5. Students agreement with Entrepreneurial Intention statements.

\begin{tabular}{|c|c|c|c|c|}
\hline No & Intentions Statement & $\begin{array}{l}\text { B1 } \\
\text { Percent }\end{array}$ & $\begin{array}{l}\text { B2 } \\
\text { Percent } \\
\end{array}$ & $\begin{array}{l}\text { Sig. } \\
P<.005\end{array}$ \\
\hline 1 & $\begin{array}{l}\text { I will choose a career as an } \\
\text { entrepreneur }\end{array}$ & 79 & 71 & .650 \\
\hline 2 & $\begin{array}{l}\text { I will make every effort to start } \\
\text { and run my own business }\end{array}$ & 90 & 90 & .672 \\
\hline 3 & $\begin{array}{l}\text { I have strong intention to start a } \\
\text { business someday }\end{array}$ & 95 & 95 & .391 \\
\hline 4 & $\begin{array}{l}\text { I have thought seriously to start } \\
\text { my own business after } \\
\text { completing my study }\end{array}$ & 84 & 88 & .061 \\
\hline 5 & $\begin{array}{l}\text { I will start my business in the } \\
\text { next } 5 \text { years after graduation }\end{array}$ & 46 & 61 & .255 \\
\hline 6 & $\begin{array}{l}\text { I will start my business in the } \\
\text { next } 10 \text { years after graduation }\end{array}$ & 45 & 62 & .287 \\
\hline & & Likely & Likely & \\
\hline 7 & $\begin{array}{l}\text { Estimating the likelihood that I } \\
\text { will start my own business or } \\
\text { become self employed on a full } \\
\text { time basis within the next } 1 \text { year } \\
\text { after graduation is... }\end{array}$ & 34 & 17 & \\
\hline 8 & $\begin{array}{l}\text { Estimating the likelihood that I } \\
\text { will start my own business or } \\
\text { become self employed on a full } \\
\text { time basis within the next } 5 \text { years } \\
\text { after graduation is... }\end{array}$ & 69 & 81 & \\
\hline
\end{tabular}

The results in Table 5 show a 10 percent drop in the number of students that 'Agreed/Strongly agreed' with the statement that 'I will choose a career as an entrepreneur'. There was no change in the numbers that agreed/strongly agreed with statements 'I will make every effort to start and run my own business', and 'I have strong intention to start a business someday'. There was a 33 percent upward movement in the number of students that agreed/strongly agreed with statements 'I will start my business in the next 5 years after graduation', and 'I will start my business in the next 10 years after graduation' after course delivery.

However, the number of students who estimated as 'likely' their likelihood of starting a business or becoming self employed on a full time basis within the next 1 year after graduation dropped by 50 percent after course delivery whilst the number of students who estimated as 'likely' the likelihood of starting a business or becoming self employed on a full time basis within the next 5 years after graduation increased by 17 percent after course delivery. The perceived difficulty of accessing capital resources and of starting and running a successful business in Malawi as discovered during the learning of entrepreneurship would have been responsible for the movement in students entrepreneurial intentions. It is very difficult to access capital for venture start-up in Malawi and the commonest source for most venture start-ups are Founder, Friends and Family. This would have influenced students' perceptions that they would not be able to start a business or become self employed 1 year after graduation but 5 years after graduation to allow time to work and save finances for venture capital requirements.

Looking at the students entrepreneurship intention statement ratings, they are already high above 70 percent at the commencement of the entrepreneurship course. That means the class had already positive entrepreneurial intentions before commencement of the entrepreneurship course. The Chi-square tests therefore showed insignificant link between entrepreneurship education and students entrepreneurial intentions. The timing of entrepreneurship education at third year of the programme does not change much the attitudes and intentions of students towards business and entrepreneurship practice. There is already positive orientation towards entrepreneurship among students in the business administration programme. Entrepreneurship education however condenses the realism of the entrepreneurship process that it is not easy to become an entrepreneur thus dropping the students estimated likelihood of starting a business in the next 1 year after graduation and increase the students estimation of the likelihood of starting a business in the next 5 years after graduation.

If entrepreneurship education has to impact positively on the economy, students attitudes and intentions have to be positive about starting a business venture in the shortest possible time after graduation. Entrepreneurship education is one element of the entrepreneurship development process. Several other factors impact the process such as the state of the economy, access to venture capital, and the environment for business. It can be presumed that students considered 
several other factors to determine the likelihood of starting their own businesses within 1 year or 5 years after graduation. The factors were not supportive to start a business in the shortest possible time after graduation and thus students were aware of these after entrepreneurship education.

The results therefore do support the Hypothesis - H4 that entrepreneurship education effects entrepreneurial intentions of students which in this case although the intentions were already high at the commencement of the module, the intentions were re-structured following the knowledge and realisations of the entrepreneurship process and requirements for success.

\section{Conclusion}

The study was conducted on third year students of the Bachelor of Business Administration in the University of Malawi to investigate the effects of the entrepreneurship course on students' entrepreneurial orientation. Therefore the study joined other empirical studies in investigating the effects of entrepreneurship education on attitudes, subjective norms, perceived behavioural control (self efficacy) and entrepreneurial intentions following observations by Collin, Hannon and Smith (2006) that little was known about the impacts of entrepreneurship education programmes on developing entrepreneurial intentions of students particularly in universities.

The research found that entrepreneurial education effects students knowledge about entrepreneurship and positively effects students self efficacy (students' perceptions of having adequate skills and competences to engage with entrepreneurship practices successfully). The study found that attitudes and intentions towards entrepreneurship practice were already positive among the Bachelor of Business Administration students, and therefore Chi Square tests established insignificant links between entrepreneurship education and students attitudes and their entrepreneurial intentions. The study further found that there was no correlation between entrepreneurship education and subjective norms. Therefore the results supported the hypothesis $\left(\mathrm{H}_{2}\right)$ that entrepreneurship education positively effects students self efficacy and weakly supported the hypotheses $\mathrm{H}_{1}$ and $\mathrm{H}_{4}$ that entrepreneurship education positively effects students attitudes towards entrepreneurship and students entrepreneurial intentions. However, the results did not support the hypothesis $\mathrm{H} 3$ that entrepreneurship education positively effects students subjective norms. The hypothesis was declined. The results strongly support Bandura (1997) and Hollenbeck and Hall (2004) who found that entrepreneurship education enhances an individual's level of self efficacy, and weakly supported Peterman and Kennedy (2003), Souitaris et al (2007) and Wilson et al (2007) who found that exposure to entrepreneurship education increases entrepreneurial intentions.

\section{Areas for Future Research}

It would be interesting to conduct similar studies on the effects of entrepreneurship education on entrepreneurial orientation of students from different cultures, experience, exposure and from non-business related programmes to eliminate any biases towards business and entrepreneurship that would have existed at the onset of this study since it was conducted on business administration students.

\section{References}

[1] Acs, Z. and Audretsch, D. (2003). Innovation and technological change, in: Z. J. Acs and D. B. Audretsch (eds.), Handbook of Entrepreneurship Research, Boston: Kluwer Academic Publishers, pp 55-79.

[2] Aidis, R. (2005). Institutional Barriers to small to medium sized enterprises operations in transition economies, Small Business Economics, Vol. 25(4), pp 305-318.

[3] Ajzen, I. (2002). Perceived Behavioural Control, SelfEfficacy, Locus of Control, and the Theory of Planned Behaviour. Journal of Applied Social Psychology, Vol. 32(4), pp665-683.

[4] Ajzen, I. (1991). The Theory of Planned Behaviour. Organizational Behaviour and Human Decision Processes, Vol. 50(2), pp 179-211.

[5] Ajzen, I. (1985). From intentions to action: A theory of planned behaviour. In J. Kuhl and J. Beckman (eds.), Action control: From cognitions to behaviour, New York: Springer,pp $11-39$.

[6] Allport, G. W. (1935). Attitudes. In C. M. Murchison (Ed.), Handbook ofSocial Psychology. Winchester, MA: Clark University Press.

[7] Armitage, C. J. and Conner, M. (2001b). Efficacy of the Theory of Planned Behaviour: A meta-analytic review. British Journal of Social Psychology, 40, 471-499.

[8] Armitage, C. J. and Conner, M. (1999). Distinguishing Perceptions of Control from Self-Efficacy: Predicting Consumption of a Low-Fat Diet Using the Theory of Planned Behaviour. Journal of Applied Social Psychology, Vol. 29(1), pp 72-90.

[9] Autio, E. (2007). Global Report on High-Growth Entrepreneurship. London Business School/Mazars/Babson.

[10] Bandura, A. (1977). Self-efficacy: toward a unifying theory of behavioural change. Psychological Review, Vol. 84, pp 191215.

[11] Bandura, A. (1986). Social Foundations of Thought and Action: A Social Cognitive Theory. Englewood Cliffs: NJ, Prentice-Hall.

[12] Bandura, A. (1997). Self-Efficacy: The Exercise of Control. New York: W. H. Freeman and Company.

[13] Benzing, C., Hung, M. C. and Orban, K. (2009). Entrepreneurs in Turkey: A Factor Analysis of Motivations, Success Factors and Problems, Journal of Small Business Management, Vol. 47(1): 58-91. 
[14] Bird, B. (1988). Implementing entrepreneurial ideas: The case for intentions. Academic Management. Review Vol.13, pp $442-454$.

[15] Brooksbank, D. and Jones-Evans, D. (2005). Global Entrepreneurship Monitor: 2005 Wales Executive Summary Report, National Entrepreneurship Observatory.

[16] Boyd, N. G. And Vozikis, G. S. (1994). The influence of selfefficacy on the development of entrepreneurial intentions and actions. Entrepreneurship Theory and Practice. Vol. 18(4): pp 63-77.

[17] Chandrashekaran, M., Mc Neilly, K., Russ, F. A., and Marinova, D. (2000). From Uncertain Intentions to Actual Behaviour: A Threshold Model of Whether and When Salespeople Quit. Journal of Marketing Research,Vol. 37(4): 463-479.

[18] Collins, L. A., Smith, A. J. and Hannon, P. D. (2006). Discovering entrepreneurship: An exploration of a tripartite approach to developing entrepreneurial capacities. Journal of European Industrial Training, Vol. 30(3): 188-205.

[19] Delmar, F. and P. Davidson (2000). Where do they come from? Prevalence and characteristics of nascent entrepreneurs. Entrepreneurship and regional development Vol. 12: 1-23.

[20] Dickson, P., Solomon, G. and Weaver, K. M. (2008). Entrepreneurial section and success: does education matter? Journal of Small Business and Enterprise Development, Vol. 15(2): pp239-258.

[21] Dollinger, M. J. (2003). Entrepreneurship: strategies and resources. Pearson International Edition, New Jersey.

[22] Donckels, R., and Miettinen, A. (1997). Entrepreneurship and SME research: on its way to the next millennium. Aldershot: Ashgate.

[23] Douglas, E. J., and D. A. Shepherd(2002). Self-employment as a career choice: Attitudes, entrepreneurial intentions, and utility maximization. Entrepreneurship: Theory and PracticeVol. 26 (3): pp81-90.

[24] Drucker, P. F. (1985). Innovation and Entrepreneurship: Practice and Principles. London: Heinemann

[25] Dumas, C. (2001). Evaluating the outcomes of microenterprise training for low income women: A case study. Journal of Developmental Entrepreneurship, Vol. 6(2), pp 97128.

[26] Elfving, J., Brannback, M., \&Carsrud, A., (2009). Towards a contextual models of entrepreneurial intentions. In A. L. Carsrud and M. Brannback (eds) Understanding the Entrepreneurial Mind (pp. 23-33)., Springer Science.

[27] European Commission (2008). Entrepreneurship in higher education, especially within non-business studies. Brussels: Final Report of the Expert Group.

[28] Fishbein, M. and Ajzen, I. (1980). Understanding attitudes and predicting social behaviour. Englewood Cliffs, NJ: Prentice-Hall.

[29] Fishbein, M. And Ajzen, I. (1975). Belief, attitude, intention, and behaviour. Addison- Wesley: Reading, MA, USA.

[30] Gird, A. and Bagraim, J. J. (2008). The theory of planned behaviour as predictor of entrepreneurial intent amongst finalyear university students. South African Journal of Psychology,
Vol. 38(4), pp 711-724.

[31] Gorman, G., and Hanlon, D. (1997). Some research perspectives on entrepreneurship education, enterprise education and education for small business management: A ten-year literature review. International Small Business Journal, Vol. 15(3): 56-77.

[32] Hébert, R. F. and Link, A. N. (1988). The Entrepreneur: Mainstream Views and Radical Critiques (Second ed.). New York: Praeger.

[33] Heinonen, J. (2007). An entrepreneurial directed approach to teaching corporate entrepreneurship at university level. Education and TrainingVol. 49(4), pp. 310-324.

[34] Hollenbeck, G. and Hall, D. T. (2004). Self-confidence and leader performance. Organizational Dynamics, Vol. 33(3), pp254-269.

[35] Hornaday, R. W. (1992). Thinking about Entrepreneurship: A Fuzzy Set Approach. Journal of Small Business Management, Vol. 30(4): pp 12-23.

[36] Johannisson, B., Landstrom, H. and Rosenberg, J. (1998). University training for entrepreneurship training - an action frame for reference, European Journal of Engineering Education, Vol. 23(4): pp 477-496.

[37] Katz, J. (2003). The chronology and intellectual trajectory of American entrepreneurship education, Journal of Business Venturing, Vol. 18(2): 283-300.

[38] Kolvereid, L. (1996). Organisational employment versus self employment: Reasons for career choice intentions. Entrepreneurship Theory and PracticeVol. 20 (3): pp23-31.

[39] Kolvereid, L. and Moen, O. (1997). Entrepreneurship among business graduates: does a major in entrepreneurship make a difference?Journal of European Industrial Training, Vol. 21(4): 154-160.

[40] Krueger, N. F. (2000). The cognitive infrastructure of opportunity emergence. Entrepreneurship Theory and Practice, Vol. 24(3), pp 5-23.

[41] Krueger, N. F. (1993). The impact of prior entrepreneurial exposure on perceptions of new venture feasibility and desirability. Entrepreneurship Theory and Practice, Vol. 18(1), pp 5-21.

[42] Kuratko, D. F. (2005). The Emergence of Entrepreneurship Education: Development, Trends, and Challenges. Entrepreneurship: Theory \& Practice, Vol. 29(5): 577-597.

[43] Linan, F. and Rodríguez, J. C. (2004). Entrepreneurial attitudes of Andalusian university students.44th ERSA Conference, Porto (Portugal), 21-25 August.

[44] Markman, G. D., Balkin D. B. and Baron R. A. (2002). Inventors and New Venture Formation: The Effect of General Self-Efficacy and Regretful Thinking. Entrepreneurship Theory and Practice, Vol. 27(2), pp149-165.

[45] Matthews, C. H., and Moser, S. B. (1995). Family background and gender: Implications for interest in small firm ownership. Entrepreneurship Regional Development, Vol.7(3), pp65-377.

[46] Mc Larty, R. (2005). Entrepreneurship among graduates: Towards a measured response. The Journal of Management Development, Vol.24(3),pp 23-238. 
[47] Nunnally, J. C. and Bernstein, I. H. (1994). Psychometric Theory $\left(3^{\text {rd }}\right.$ Eds) McGraw-Hill, New York, NY.

[48] Osborne, S. W., Falcone, T. W., and Nagendra, P. B. (2000). From unemployed to entrepreneur: A case study in intervention. Journal of Development Entrepreneurship, Vol. 5(2), pp15-136.

[49] Peterman, N. E. and Kennedy, J. (2003). Enterprise Education: Influencing students' perception of entrepreneurship. Entrepreneurship Theory and Practice, Vol. 28(2), pp 129145.

[50] Rae, D. (2006). Entrepreneurial learning: A conceptual framework for technology-based enterprise. Technology Analysis \& strategic Management, Vol.18(1), pp. 39-56.

[51] Robinson, P. and Sexton E. (1994). The effect of education and experience on self employment success, Journal of Business Venturing, Vol. 9(2): 141-156.

[52] Schumpeter, J. A. (1934). Theory of Economic Development. Cambridge, MA: Harvard University Press.

[53] Schwarz, E., Wdowiak, M., Almer-Jarz, D. and Breitenecker, R. (2009). The effects of attitudes and, perceived environment conditions on students' entrepreneurial intent: An Austrian perspective, Education and Training, Vol. 51(4): pp 272-291.

[54] Scott, M. G., and Twomey, D. F. (1988). The Long Term Supply of Entrepreneurs: Students' Career Aspirations in Relation to Entrepreneurship. Journal of Small Business Management (October) pp 5-13.
[55] Shane, S., and Venkataraman, S. (2000). The Promise of Entrepreneurship as a Field of Research. The Academy of Management Review,Vol. 25(1): pp 217-226.

[56] Shapero, A. (1982). Social Dimensions of Entrepreneurship. In C. Kent, D. Sexton and K. Vesper, eds., The Encyclopaedia of Entrepreneurship. Englewood Cliffs: Prentice-Hall, pp 7290 .

[57] Sheppard, B. H., Hartwick, J. and Warshaw, P. R. (1988). The Theory ofReasoned Action: A Meta-Analysis of Past Research withRecommendations for Modifications and Future Research. Journal ofConsumer Research, Vol. 15(3).

[58] Souitaris, V., Zerbinati, S., \& Al-Laham, A. (2007). Do entrepreneurship programmes raise entrepreneurial intention of science and engineering students? The effect of learning, inspiration and resources. Journal Of Business Venturing, Vol. 22(4), pp 566-591.

[59] Wilson, F., Kickul, J. and Marlino, D. (2007). Gender, entrepreneurial self-efficacy, and entrepreneurial career intentions: Implications of entrepreneurship education. Entrepreneurship Theory and PracticeVol. 31 (3): pp387- 406.

[60] Zeithaml, C. and Rice, G. (1987). Entrepreneurship/small business education in American Universities. Journal of Small Business Management, Vol. 25(1), pp 44-50. 